\title{
Psychotherapy for Parents with Trauma and Attachment Difficulties
}

\author{
Lynne Holdem
}

Psychotherapist, NeW Plymouth

\begin{abstract}
This paper describes the arousal of therapist concern regarding the well-being of children in families where there is parental mental illness and domestic violence; a vignette demonstrates how this is understood by the therapist and processed in the therapeutic relationship. The consequent development of a small pilot to provide psycho-education and peer support to caregivers and children with parents who have mental illness in a group setting is described. Reflections are then given, following from the evaluation of this group, on the need for public funded, attachment informed, family focused therapeutic interventions for caregivers with infants, children and young people who are deemed at risk because of insecure or disorganised attachment or behavioural difficulties.
\end{abstract}

\section{Whakarāpopotonga}

E whakaahua ana tēnei pepa i te whakaohonga ake o te mānukanuka o ngā kaihaumanu e pā ana ki te hauora o ngā tamariki e pāngia ana te matua whāea rānei i te mate hinengaro me te whakarekereke-ā-whare; he whakaaturanga tā tētahi pito i tā te kaihaumanu arotau me te tukanga i roto $\mathrm{i}$ te here haumanu. Ka whakaahuatia te whanaketanga i ara ake mai i têtahi maramara whakamātautau ki te whakarato mātauranga-hinegaro, pou aropā hoki ki ngā kaiāwhina me ngā tamariki whai mātua mate hinengaro i roto rōpū. Ka whakaputahia ake ngā tirohanga i muri mai i te arotakenga o tēnei rōpū, mō te whai pūtea matawhānui, mātauranga here, haumanu takawaenga arotahi whānau mō ngā kaiāwhina whiwhi kōhunganga, mō ngā tamariki me ngā taiohi e whakaarohia ana kei te whakamōrea nā te here kaumingomingo here tītengi rānei, te whanoke rānei.

Keywords: attachment; poverty; parenting; vulnerable children; supporting families; children of parents with mental illness

Holdem, L. (2017). Psychotherapy for parents with trauma and attachment difficulties. Ata: Journal of Psychotherapy Aotearoa New Zealand, 21(1), 29-41. https://doi.org/10.9791/ajpanz.2017.04 @ New Zealand Association of Psychotherapists Inc. 


\section{Introduction}

I find it especially troubling when a patient speaks about one of her children in ways which reveal the possibility of abuse or neglect. Fraiberg, Adelson and Shapiro (1975) described a repetition in which "the parent ... is condemned to repeat the tragedy of their childhood with their own baby in terrible and exacting detail” (p.388).

Anxiety is aroused when patients speak of their child cast in the role of perpetrator or rescuer, and themselves as victim. The child stands in for their younger self and they assume unconsciously a perpetrator role in an identification with the aggressor (Freud, 1937). Although the behaviours may not merit an Oranga Tamariki (New Zealand's Ministry for Vulnerable Children) notification, I find it hard to bear the fear that a child may not have a good enough experience of safe haven and secure base with their parent (Bowlby, 2000).

\section{The Unmothered Child as Mother}

Ursula, a handsome woman of forty years, arrives in pursuit of a small boy, who it turns out is her son Isaac, seven years old. “The baby sitter didn't come”, she says ruefully. I heard Isaac complaining loudly as they stepped out of the lift. I commiserate with him, attempting to put into words for him the strangeness of coming to see this old woman. He softens gradually and starts drawing a big rocket with explosions coming out of it. By the end of Ursula's appointment, he is hiding the sand-tray toys around my room. Twinkling with mischief and entitlement, he protests loudly when I ask him to tidy up.

A few weeks earlier Ursula towed in her equally reluctant partner Zac. She complains frequently of his drinking and paranoid accusations of infidelity. Ursula teeters on the verge of leaving but then tries to convince me of how Zac really loves her. Who else would tolerate her? Zac is on home detention because he assaulted Ursula. A sturdy, good looking scaffolder, he provides sarcastic commentary to everything she says, as if to put Ursula in her place or spoil my regard for her. I am a bit charmed by his dismissive teasing and his superficial surfer cool. He is a smiling assassin. I squirm a little for Ursula, so tolerant and kind despite the denigration. His accusations seem to be projections of his own inadequacies. I try to catch his word darts and invite enquiry: "Your jokes seem to say you don't value Ursula, but maybe they really show how much you value her, how scary love is for us all?"

Both Ursula and Zac struggle with splitting defences. Neither have integrated good and bad objects, illustrating Fairbairn's theory of splitting an object into exciting object and rejecting object and ego into libidinal ego and anti-libidinal ego (Fairbairn, 1994). As Celani (2010) explained:

The whole purpose of splitting is to keep these two separate views of the object apart so that the deprived child's libidinal ego can continue loving and longing for the exciting object while the antilibidinal ego can fight back against the rejecting aspects of the very same object with all its energy, without the libidinal ego (or the central ego) ever knowing. (p. 6o)

When Ursula goes home, Zac accuses her of infidelity. Separation threatens him, activating paranoid-schizoid mental states, and perhaps Ursula becomes a rejecting object. 
Identified with anti-libidinal ego in relation to rejecting object, he threatens her (miscues his unconscious need for reassurance), triggering traumatic affect from childhood experiences of her emotionally-escalated and self-harming mother. Previously she would have escalated with him and violence from one or both may have resulted. Now she withdraws and he responds by bombing her with accusatory texts until, fed up, she stops replying. His aggression then melts into needy desperation, an illustration of Crittenden's Type C attachment strategy designed to maintain Ursula's availability to him. "Angry omnipotence is alternated with disarming displays of tender vulnerability" (Crittenden, 2005, p. 5). Now identified with libidinal ego, she becomes the exciting object he longs for. This evokes Ursula's caregiving attachment response. Soon she is back in his arms. Thus she adapts to Zac's moods and threats in the way that Lyons-Ruth (2007) described the parentified child maintaining proximity to mother: "Her self-development becomes subordinated to maintaining her mother's mood and averting and managing hostile undercurrents in the relationship" (p. 24).

Recently Ursula told me Isaac had said he wanted to kill her with a knife. My focus is captured by anxiety about her son. It certainly seems like Isaac cannot turn to Ursula to cue his need for emotional regulation and comfort and he reacts like Zac or Ursula's mother with threat and emotional escalation, in order to gain her attention. When I find out they stayed the weekend at Zac's house I suggest it might be hard for Isaac having Mum to himself and then having to share her again with Zac. Perhaps Isaac feels all the surges of threat and turbulence in their relationship but is only safe enough to vent his distress when not in Zac's presence.

Ursula reveals she has been getting a baby-sitter every night so she can sleep with Zac. I feel shocked. No wonder Isaac is acting crazy. It is his first week back at school, with a new teacher and class, and in the past he has been bullied. Isaac must feel his mother's absence at home. I wonder how her love for her son seems to be so eclipsed by Zac. Her own separation anxiety is triggered and she has an awful phantasy of Zac being with another woman. She is terrified by thoughts of breaking up with him. Ursula would rather be the bad one than have Zac be bad - "He's really a good man, he works really hard. I can be pretty impossible”. This is Fairbairn's moral defence (Fairbairn, 1994).

At such times, I risk becoming a superego figure to Ursula. Probably I am triggered by my own attachment distress. When I was little and my mother was helping milk cows, I would be left in the care of my two brothers, a lonely and frightening experience. These emotional tides roll over me and I attempt to quieten my feeling but still use it: "You are caught between wanting to avoid an emotional storm with Zac and your care for your boy? ... What's that like for you? ... Can you help me understand what happens inside you....and what you think Isaac might feel and need for you? ... to know you are there, being with him, protecting him? ... It is so hard to give what you didn't receive".

The following week she talks about a new schedule of reading to Isaac before bed. This was enjoyable for both of them and he was more co-operative. Reading together was her idea. She appeared to have accepted my challenge regarding his need but remained free to think about how to meet it. It is reassuring that my directness hasn't damaged the therapeutic alliance and, even more, that she has been able to think about and make use of the reflection I offered. 
Ursula says she is beginning to accept the presence of anxiety when she is alone and trying to treat it like background music. In time her attachment to her exciting and frustrating external object, Zac, may gradually become less adhesive as she internalises ego structuring memories of support from her relationship with me. This may mean she is more able to differentiate from her bad objects. She seems more able to self-soothe and less prepared to accept Zac's accusations and denigration.

Anxiety about neglect or abuse can induce manic reparation responses and I talk too much or soothe in a frantic way. Sometimes a foggy indifference takes over, possibly a concordant counter-transference to a patient's dissociation. Caring too much or not enough are familiar ways my own defence diverts awareness from feelings, once unbearable. Other times my uninvolved witness begins to judge and possibly persecute through unspoken, yet visible, thoughts and feelings. My omnipotent rescuer entertains fantasies of fixing by putting pressure on the patient to change. The more identified I become with wanting Ursula to change, the more I risk arousing resistance. Carl Jung said, "We cannot change anything unless we accept it. Condemnation does not liberate, it oppresses" (1955, pp. 234-235).

It is important to observe and understand counter-transference when working with clients like Ursula and to assess their therapeutic window and use trial-identification before making an intervention related to their relationship with their children in order to avoid shaming them, provoking a punitive response towards the child or flight from therapy.

Ursula was committed to therapy and we continued to include her child and her partner in our conversations although they did not revisit in person. I became more able to listen for echoes of the patient's vulnerable child part and help her see her past in the present. She gradually developed more reflective ability and insight into her own repressed aggression and neediness that Zac reflected. Increasingly she was able to stay with and contain her feeling when she was triggered by her child or spouse, without withdrawal or retaliation, and to see her child's "bad behaviour" instead as a clue to his need.

\section{Hands to Hold the Parent}

Psychotherapy is a slow business, especially with people with complex Post-Traumatic Stress Disorder, or attachment styles that have hardened into character traits. Children cannot wait for their parents to become "good enough" (Winnicott, 1973). I wish the un-mothered mothers I have worked with had access to early-intervention parenting support that was therapeutic and relational rather than behaviourist and generic. Possibly, there is "no such thing as a patient", but there is always a patient and their family? Here is a role for publicfunded, family-minded psychotherapy with a complementary role for public-minded psychotherapists.

Taking on the role of manager of Supporting Families in Mental Illness, Taranaki provided me an opportunity to trial an innovative service for families like Ursula's. Consumers of mental health services often lack opportunities for social connection, identity formation and experiencing agency. I wanted to see if small groups could be used to make a personal, intimate social environment available to caregivers and their children while increasing their social connection, belonging and accountability (Block, 2009).

I was seeking an intervention that could be upscale; affordable; worked with both parents 
and children separately but in a connected way; helped them find words for feelings; developed self-reflective capacity, empathy, and problem-solving; found strategies for selfsoothing and emotional regulation; reduced stigma and created connections with others experiencing similar difficulties.

In 2012 I attended a conference organised by Children of Parents with Mental Illness or Addictions (COPMIA). Suddenly, the set of children I had been concerned about had a name, and research about treatment for them was available (Solantaus, Paavonen, Toikka, \& Punamäki, 2010; Solantaus \& Toikka, 2006; Solantaus, Toikka, Alasuutari, Beardslee, \& Paavonen, 2009).

After consultations with family members and other professionals I developed a plan to work with a small group of mothers while an art therapist worked simultaneously with their children in a room nearby. While we debriefed, a volunteer would drive families home. Twelve children from six families and their mothers attended. Parents and children met with one of the facilitators to assess their suitability for group support in their own home. The aim of combining psycho-education and peer support to foster resilience was explained to the parents and informed consent obtained. Family history, school attendance and behaviour, and parental perception of child's strengths and challenges as well as interviewer observations of the state of mind of the parent and their ability to use a group and integrate information (Crittenden, 2005) informed the assessment of their suitability for the group. No families were excluded however.

When I pulled up to Sandra's house her eight-year-old son Jacob appeared at my car window, smiling and waving a big stick. Jacob ushered me in to his mother, a large young woman lying on the couch. Sandra said, "You've met my ADHD kid!" Jacob had been returned to Sandra's care after some years in foster placements. I suspected Jacob's friendly greeting disguised anxiety. My arrival possibly evoked previous social worker visitations and threatened change. Perhaps he was protecting his mother from me. I liked them both immediately and they engaged with me quickly, rather too quickly. Jacob appeared in attachment terms "over-bright" (Powell, 2014, p. 144) and controlling in a way common to children of parents with mental illness or addiction. When a parent is, in Circle of Security (Powell, 2014, pp. 76-77) vocabulary, "mean, weak, or gone" rather than "bigger, stronger, wiser, and kind" a role-reversal occurs in which the child appears to give up on object seeking but maintains proximity by caregiving (Powell, 2014).

For boys, there is more often a controlling and aggressive response or an alternating combination of clingy and aggressive behaviour. Jacob showed a younger, less verbalised model of the charm, control and threaten strategy Zac was using in relationship with Ursula. This was described by Fonagy (1999):

When confronted with a frightened or frightening caregiver, the infant takes in as part of himself or herself the mother's feeling of rage, hatred, or fear, and her image of the child as frightening or unmanageable. This painful image must then be externalised for the child to achieve a bearable and coherent self-representation. The disorganised attachment behaviour of the infant, and its sequelae-bossy and controlling interactions with the parent-permit the externalisation of parts of the self and limit further intrusion into the self-representation. (p.18) 
Aggressive behaviour can compel the parent to resume authority and thus reactivate the parent's own caregiving system that she has temporarily abandoned (Fonagy, 1999).

While Jacob spun in and out of the house talking rapidly with equal parts charm and malice, Sandra described barricading herself away so she could sleep. She frequently called the police because he refused to go to school. Sandra described Jacob as aggressive. He threw things. I felt he was directing a crusade to engage and control his mother. He may have experienced her as weak and frightening because of her tendency to collapse into helplessness or withdraw in the face of his aggression. A strategy she had no doubt developed as a survival response to her historic abuse.

In the parents' group Sandra relaxed and opened up. She revealed a distressing history of childhood abuse and neglect. Foraging hungrily on the snacks provided, she created a home for herself in the small group of five mothers. Enjoyed by us, she readily showed vulnerability and self-deprecating humour that seemed both a defence against shame and a display of some self-acceptance. Similarly, Jacob, being the youngest of the children's group, became their mascot.

Psycho-education content was given only in response to cues from the participants to allow an experience of authoring the group themselves. The children's group was called the Up group and the parents decided to name their group Us. They were beginning to feel at home with each other and me. We listened to, and validated, contributions of the participants to model holding and being with, to encourage belonging and agency.

In the short time of the group Sandra appeared to start taking in experiences of myself and other group members as a validating and nurturing holding environment. At the end of each group the children came to collect their mothers, usually with Jacob in the lead. I saw him run, face lit like a lamp, excitedly clutching a drawing to give Sandra. I saw Sandra's body slump, an audible sigh, as she turned back towards the other women. "The group isn't long enough," she said. She was being asked to give something she needed for herself. Jacob barely skipped a beat, launched himself at Sandra with his drawing held out like a weapon. He pulled up right before impact and thrust the drawing into Sandra's lap.

When the pilot ended with no further funding available, parents continued to meet on a voluntary basis for a few months until we decided to close. Most of the teens kept in touch with the agency and call on us when needed. Occasionally one has organised a social event for COPMIA teens at our premises. Six months after the official pilot Supporting Families was given a contract for COPMIA work.

An evaluation (Doehring \& Holdem, 2015) confirmed some of the existing knowledge about the stressors experienced by COPMIA families. These include: absent fathers, poverty, confusing and conflicting involvement of multiple agencies, abandonment by services, generic services that do not meet individual needs, stigma and bullying, disruption of parenting capacity and social isolation. What was most valued by participants in their unstructured interviews, was "the experience of a place of safety, acceptance, non-judgement and the social connection for both adults and children" (Doehring \& Holdem, 2015, p. 14).

Although the project showed promise, I would not try such a short-term intervention again. A few sessions of counselling as offered by agencies under brief government contracts only disappoint. Adult victims of abuse and neglect are not just filled with bad internal objects but empty of good ones. New and consistent "good enough" experiences of support 
need to be taken in as positive introjects to restructure the patient's internal world. If therapy is brief the patient will experience the therapist as yet another exciting or frustrating object. Crittenden (2005, pp. 8-11) provided a clear model for appropriate interventions for differing attachment types and abilities to process information from preconscious (implicit) to conscious (explicit and verbal) to consciously reflective (integrative).

Communication with both parents and teenagers was difficult due to lack of phones or data. Children from the families complained about lack of food and phones at home, bullying at school, and teachers unaware of the stresses and responsibilities they experienced when parents were unwell or they were called on to look after younger siblings. It was apparent from what was said at post group interviews and in group sessions that economic hardship added significantly to the existing stresses of parental mental illness on the children and young people as well as on their parents.

Much later I saw Sandra in the street. She told me things were going "alright". Jacob was still in her care. She said what she missed most about the group was it was something they could do together. They could talk about it when they got home. In hindsight Sandra needed an attachment-informed family therapy that could help her be with Jacob, protect and take charge of him, instead of withdrawing from him and repeating the abandonment he must have felt when he was uplifted. Although Child Youth and Family had intervened in a care and protection role when Jacob was young, little had been done to help Sandra rebuild his trust or manage his behaviour on return to her care. Unless Oranga Tamariki is funded, or social workers trained, to provide therapeutic services to the caregivers of children who have been uplifted from neglecting or abusive environments, the placements will continue to unravel. Two hundred and eighty of the children in state care had more than three caregivers in 12 months in 2011 (Ministry of Social Development, 2015). Difficult behaviours generated by their distrust, fear of abandonment and disorganised attachment upend good intentions. Caregivers need support to interpret behaviours as signals of trauma and miscues of attachment need, and to become hands that are strong enough to hold the children in their care.

Secure attachment is a protective factor for vulnerable children (Atwool, 2007). The resilience of children like Jacob could be fostered by early therapeutic interventions, individualised and attachment-focused parenting supports, opportunities for cultural belonging and recreational interests for children.

I continue to think that a two-group model with liaison between the facilitators would be a good model to use with COPMIA families; a cost-effective, practical way to disseminate some of the useful aspects of psychotherapy to vulnerable people who would be unlikely to access psychotherapy otherwise. It was challenging to engage the parents in joining a group and to remove the barriers to participation such as transport to the group but the opportunity for their children to participate in arts therapy and social outings was enough to get some reluctant mothers through the door. What kept them in was the opportunity to care and be cared for. This capacity for care is renewable and free. For isolated one-parent families, the most vulnerable in terms of outcomes for their children, a small group can provide a different kind of home than the home participants grew up in but could not be "at home" in.

I am discovering that community work is attachment work too. Peter Block said: “The 
essential challenge is to transform the isolation and self-interest within our communities into connectedness and caring for the whole" (Block, 2009, p.1). Could it be that there is no such thing as a family - there is a family and something ... a community?

\section{Circle of Security Groups}

Witnessing the reunions of mothers and children at the end of each group brought to mind Ainsworth's strange situation (1979). These experiences encouraged a search for earlier interventions for families like Sandra's that could repair attachment and improve relationships before children were older and less flexible, parents less hopeful and relationships more difficult to change. Circle of Security researchers and clinicians (Powell, Cooper, Hoffman, \& Marvin, 2014) have integrated 50 years of object relations and attachment research into a group based, clinical intervention evidenced by a number of studies (Hoffman, Marvin, Cooper \& Powell, 2006; Kohlhoff, Stein, Ha \& Mejaha, 2016; Pazzagli, Laghezza, Manaresi, Mazzeschi \& Powell, 2014). I discovered the Circle of Security Parenting (COS-P) which aims to increase parents' reflective capacity - thinking about their relationship with their child and the meaning of their child's behaviour in terms of how they cue (or miscue) their needs. I then trained in Circle of Security assessment and treatment planning.

Supporting Families developed a COS-P service to Taranaki families. Programmes are delivered by two trained social workers using videotaped parent-child interactions. We have run four parenting groups and have received funding for eight more groups. We have tested pre- and post-groups for Parenting Sense of Competence and Maternal Attitudes. There is evidence of sustained positive change shown in these measures. Participants enjoyed and stayed connected following the group. Comments from one group include:

- "I don't care so much about what other people think. I used to get so anxious if my child cried in public. I'm much more confident now."

- "I sit with him when he is 'melting down', rub his back and offer a hug, and he takes the hug when he is ready."

- "You live with more love when you are OK with things."

- "I used to be scared of her and now I'm not."

We are working towards providing the intensive COS service, a twenty-week group which begins with a Strange Situation and Adult Attachment interview and uses moments of videotape to provide an individualised treatment that factors in the core attachment sensitivity of the parent and the lynchpin need of the parent-child dyad.

Parenting programmes that are behaviourist and didactic are if anything counterproductive for children with insecure attachment as they tend to make parents more punitive because they are focused on the child's behaviour as the problem, not the relationship between the child and the parent. A holistic family service that can offer longer term psychotherapy, or attachment informed family therapy, that helps caregivers process their own trauma and develop reflective capacity is needed.

There is social and institutional pressure put on mothers like Ursula and Sandra to work, 
and put children in factory-like childcare settings while the government congratulates itself that they are doing vulnerable children a favour. This only exacerbates stress for children with insecure attachment.

The insecure nature of rental accommodation for low-income families is also problematic. The children of families that move frequently give up on developing friendships and attachments to neighbours, teachers and parents of friends. If the child's home base is stable these can provide opportunities to develop an internal working model of relationship, different to the one modelled by their primary caregiver, contributing to "earned security". Also, family and neighbours can provide stimulating activities and social interaction lacking in the house of a depressed or poor parent. Economic hardship and the threat of eviction loom large as sources of stress for parents and create barriers to community supports that could otherwise off-set some of the disadvantages created by parental mental illness.

\section{The Hands of the State}

John Bowlby said, "If a community values its children it must cherish their parents" (Bowlby, 1951, cited in Bretherton, 1992, p. 762 ).

Currently income inequality, poverty, homelessness, low wages and lack of employment opportunities add stress to families. Stress which often presents as domestic violence and mental illness and increases the likelihood of insecure and disorganised attachments developing. Minister Anne Tolley intends to reduce children in state care from thousands to hundreds by focusing on a child-centred, harm prevention model (Kirk, March 31, 2017). However, "vulnerable children" do not exist separately from their parents and the communities around them, and a good enough society protects children's attachment experience and prevents the marginalisation of the most vulnerable through fair distribution of income and other resources.

Research by Costello, Erkanli, Copeland and Angold (2010) revealed "lower rates of psychopathology in American-Indian youth following a family income supplement, compared with the non-exposed, non-Indian population, and this persisted into adulthood" (p. 1954). A living wage or universal benefit could perhaps reduce prevalence of mental illness and substance use disorders in our young people if it was provided to their families at an early enough age.

Māori researchers are especially concerned about the over representation of Māori babies and children being uplifted into state care or placed in youth justice facilities and the ongoing collective and inter-generational damage from violence, insecure attachment and loss of knowledge of whakapapa, identity and whanaungatanga (Fleming 2016; Hall, 2015; Moyle, 2015).

The scientific facts are now in on the consequences of early attachment experience, having lifelong impact on relationships, school behaviour and learning, mental health and resilience (Atwool, 2007; Crittenden, 2005; Stroufe's Minnesota Longitudinal Study of Risk and Adaptation as cited in Van der Kolk, 2014). The Dunedin Study also showed there is economic as well as emotional sense in targeting assistance to troubled families (Poulton, 2016). Vulnerable families with children need a chance to get their relationships right 
before the state intervenes, adding to the five thousand children now in state care (Kirk, 2017).

Attachment theory describes a basic lifelong human need for a close and intimate relationship. It therefore stands at odds and challenges many of the values of contemporary western societies - that human emotional life (and women's contribution to the care of infants and elderly) is not valued; that rationality alone should guide decision-making. As if government policies were directed by people who had given up on object seeking and instead become preoccupied with the autistic consolations of technology and material wealth, like avoidant children, backs turned to the other, reaching for anything, no longer feeling the need for connection but governed by its absence.

Fonagy (1999) wrote:

I believe that disorganised attachment ... can occur at least in part because society has relinquished its care-taking function, demolished its institutions for supporting emotional development and shifted its priorities from the mental and emotional to the material. In the increasing violence around us we may be seeing the casualties of this cavalier approach. (p. 23)

A good-enough society could evolve if government policies and practices in education, health, social work, housing, and employment were structured with a fundamental valuing of our human need for attachment.

Parents are the hands that hold their children and in turn they are held by the grandparents and other family or hapu members. These hands in turn are nested in connections to neighbours, friends, work-mates, a promise of home from a community that also provides support to families, parents and children. Hands nested in other hands. Finally, there are the hands of the state. We can't keep vulnerable children safe without creating the conditions that allow families to provide safe and secure attachment experiences and foster for connected and caring communities.

\section{Conclusion}

Psychotherapists, and other professionals, that work with parents or caregivers with parenting difficulties due to trauma and inter-generational insecure attachment need to observe and manage their own attachment responses and monitor therapeutic alliance closely.

The needs of children of patients can be factored into treatment if parents feel sufficiently held in the therapeutic relationship and the interventions offered, whether in individual or group treatment, are in the parent's window of proximal development.

Social, cultural and economic factors impact on the well-being and secure attachment of children and families. Early-intervention family-centred attachment psychotherapy can increase parental sensitivity to the attachment cues of their young children and create opportunities to foster more secure and protective attachment in vulnerable families and marginalised social groups. 


\section{References}

Ainsworth, M. S. (1979). Infant-Mother attachment. American Psychologist, 34(10), 932-937. https:// doi.org/10.1037/0003-066X.34.10.932

Atwool, N. (2007). The role of secure attachment as a protective factor for vulnerable infants. Social Work Now, $38,11-20$. Retrieved from http://www.thehub.superu.govt.nz/project/ role-secure-attachment-protective-factor-vulnerable-infants

Block, P. (2009). Community: The structure of belonging. San Francisco, CA: Berrett-Koehler.

Bowlby, J. (2000). Separation: Anxiety and anger. New York, NY: Basic Books.

Bretherton, I. (1992). The origins of attachment theory: John Bowlby and Mary Ainsworth. Developmental Psychology, 28(5),759-775. https://doi.org/10.1037/0012-1649.28.5.759

Celani, D. P. (2010). Fairbairn's object relations theory in the clinical setting. New York, NY: Columbia University Press.

Costello, E. J., Erkanli, A., Copeland. W., \& Angold, A. (2010). Association of family income supplements in adolescence with development of psychiatric and substance use disorders in adulthood among an American Indian population. Journal of the American Medical Association, 303(19), 1954-1960. https://doi.org/10.1001/jama.2010.621

Crittenden, P. M. (2005). Attachment and early intervention. Address presented at The German Association of Infant Mental Health in Hamburg, Germany. Retrieved from http:// familyrelationsinstitute.org/include/docs/attachment_early_intervention.pdf

Doehring D., \& Holdem, L. (2015). COPMIA project evaluation for SF Taranaki. Retrieved from http://www.communityresearch.org.nz/research/copmia-project-evaluation-report-for-sftaranaki/

Fairbairn, W. R. (1994). Psychoanalytic studies of the personality. New York, NY: Routledge.

Fleming, A. H. (2016). Ngā tāpiritanga: In what ways are indigenous Māori perspectives on attachment similar to and different from Western psychoanalytic perspectives on attachment and what are the implications for the practice of psychotherapy in Aotearoa New Zealand? (Master's thesis). Retrieved from aut.researchgateway.ac.nz/bitstream/handle/10292/10510/FlemingA. pdf?sequence $=3$ \&isAllowed $=\mathrm{y}$.

Fonagy, P. (1999). Male perpetrators of violence against women: An attachment theory perspective. Journal of Applied Psychoanalytic Studies, 1(1), 7-27. https://doi. org/10.1023/A:1023074023087

Fraiberg, S., Adelson, E., \& Shapiro, V. (1975). Ghosts in the nursery: A psychoanalytic approach to problems of impaired infant-mother relationship. Journal of the American Academy of Child Psychiatry,14(3), 387-421. Retrieved from http://www.jaacap.com/article/Sooo2-7138(o9)61442$4 / p d f$

Freud, A. (1937). The ego and the mechanisms of defence. London, UK: Karnac Books.

Hall, A. (2015). An Indigenous Kaupapa Māori approach: Mother's experiences of partner violence and the nurturing of affectional bonds with tamariki (Doctoral thesis). Retrieved from aut. researchgateway.ac.nz/bitstream/handle/10292/9273/HallA.pdf?sequence $=4$

Hoffman, K. T., Marvin, R. S., Cooper, G., \& Powell, B. (2006). Changing toddlers' and preschoolers' attachment classifications: The circle of security intervention. Journal of Consulting and Clinical Psychology, 74(6), 1017-1026. https://doi.org/10.1037/0022006X.74.6.1017

Jung, C. (1955). Modern man in search of a soul. New York, NY: Harcourt Brace. 
Kirk, S. (2017, March 30). Record numbers of children in the care of CYF as Govt prepares for new era in state care. Retrieved from http://www.stuff.co.nz

Kirk, S. (2017, March 31). New govt ministry to drastically cut number of kids in state care. Retrieved from http://www.stuff.co.nz

Kohlhoff, J., Stein, M., Ha, M., \& Mejaha, K. (2016). The circle of security parenting (COS-P) intervention: Pilot evaluation. Australian Journal of Child and Family Health Nursing, 13(1), 3-7. Retrieved from http://search.informit.com.au/documentSummary;dn=140733276138781;res=I ELHEA

Landa, S., \& Duschinsky, R. (2013). Crittenden's dynamic-maturational model of attachment and adaptation. Review of General Psychology,17(3), 326-338. https://doi.org/10.1037/a0032102

Lyons-Ruth, K. (2007). The interface between attachment and intersubjectivity: Perspective from the longitudinal study of disorganized attachment. Retrieved from http://www.changeprocess. org/sites/default/files/documents/The\%2oInterface\%2oBetween $\% 20$ Attachment $\% 20$ and\%2oIntersubjectivity.pdf

Ministry of Social Development. (2015). Outcomes for children and young people in care. Retrieved from http://www.msd.govt.nz/documents/about-msd-and-our-work/work-programmes/ investing-in-children/references/1-outcomes-for-children-in-care.pdf

Moyle, P. C. (2015). Māori-Lived-Experiences of the family group conference: A selection of findings. Academia.edu. Retrieved from www.academia.edu/10578356/M\%C4\%81ori-LivedExperiences_of_the_Family_Group_Conference_A_selection_of_findings

Pazzagli, C., Laghezza, L., Manaresi, F., Mazzeschi, C., \& Powell, B. (2014). The circle of security parenting and parental conflict: A single case study. Frontiers in Psychology, 5, 887. https://doi. org/10.3389/fpsyg.2014.00887

Poulton, R. (2016). Childhood disadvantage strongly predicts costly adult life-course outcomes. Retrieved from http://dunedinstudy.otago.ac.nz/news-and-events/article/53

Powell, B., Cooper, G., Hoffman, K., \& Marvin, B. (2014). The circle of security intervention: Enhancing attachment in early parent-child relationships. New York, NY: Guilford Press.

Solantaus, T., Paavonen, E. J., Toikka, S., \& Punamäki, R.-J. (2010). Preventive interventions in families with parental depression: Children's psychosocial symptoms and prosocial behaviour. European Child e Adolescent Psychiatry, 19(12), 883-892. https://doi. org/10.1007/s00787-010-0135-3

Solantaus, T., \& Toikka, S. (2006). The effective family programme: Preventative services for the children of mentally ill parents in Finland. Journal of Mental Health Promotion, 8(3), 37-44. https://doi.org/10.1080/14623730.2006.9721744

Solantaus, T., Toikka, S., Alasuutari, M., Beardslee, W. R., \& Paavonen, E. J. (2009). Safety, feasibility and family experiences of preventive interventions for children and families with parental depression. International Journal of Mental Health Promotion, 11(4), 15-24. https://doi.org/10.108 o/14623730.2009.9721796

Van der Kolk, B. (2014). The body keeps the score: Brain, mind and body in the healing of trauma. New York, NY: Viking.

Winnicott, D. (1973). The child, the family, and the outside world. London, UK: Penguin Books. 


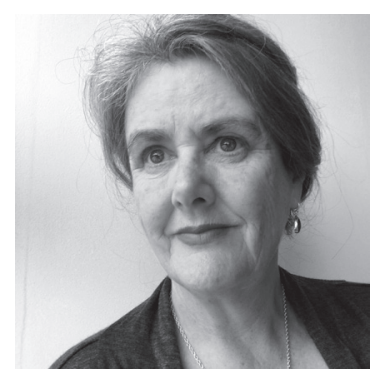

Lynne Holdem is a registered psychotherapist with an interest in family work and the intersection of politics and psychotherapy. She trained with the Institute of Psychosynthesis and joined NZAP as an applicant member in 2001. She has a private practice in New Plymouth and has also worked, as a manager, with Supporting Families in Mental Illness, Taranaki. She has worked recently in the Children's Issues portfolio for NZAP. Lynne was elected to Council in 2017, with responsibility for the Public Issues portfolio. Lynne is a trustee of Community Taranaki. Contact details: lynneholdem@gmail.com . 